\title{
Ett kollektivt flickigt kunskapsprojekt
}

Forsell, Linda, red. 2019. Girling together: A dialogue. Ett samverkansprojekt mellan scenkonstnärer och fickforskare om fickan i kulturen. Malmö: Universus Academic Press. (I 16 sidor)

GIRLING TOGETHER: A DIALOGUE är resultatet av ett samverkansprojekt mellan scenkonstkollektivet PotatoPotato och nätverket Flickforsk! Nordic Network for Girlhood Studies. Denna samling korta reflexiva texter, författade av scenkonstnärer och flickforskare, springer ur ett gemensamt utforskande av kulturella representationer av ung femininitet. Arbetet har skett genom bland annat workshops, föreläsningar och residens där skådespelare och akademiker besökt varandras arbetsmiljöer. Vad som förenar texterna är inte bara flicktematiken, utan även den övergripande frågan om vad konstnärer och forskare kan lära av varandra och varandras metoder. I denna recension kommer ett urval av antologibidragen att behandlas.

Som projektledaren och redaktören Linda Forsell betonar i antologins inledning, tenderar flicktematikens subversiva potential att förbises inom såväl feministiskt tänkande som inom scenkonst. En orsak till detta beskrivs i genusvetaren Kajsa Widegrens bidrag. Widegren belyser hur det flickiga många gånger konstrueras i motsats till det feministiska genom att flickan får representera det förflutna, och lokaliseras till ett temporalt innan ett feministiskt uppvaknande. Att bli feminist fram- 
ställs på så vis som att ingripa i tiden och rädda den flicka man antas ha varit från sin ännu-inte-emanciperade tillvaro, en tillvaro präglad av underordning och ytlighet. Detta hegemoniska narrativ gestaltar det flickiga som det man behöver göra sig av med för att kunna göra feministiskt motstånd.

Detta narrativ godtas emellertid inte av de medverkande i projektet. Tvärtom intresserar de sig för hur flickpositionen öppnar upp för andra former av varande än de som upphöjer vuxenhet, rationalitet och maskulinitet, och de tar fasta på det politiskt radikala och potentiellt utopiska i nedvärderade praktiker förknippade med flickor. Förväntningar på att lägga band på sin flickighet för att framstå som kompetent och respektingivande innebär att former av vetande och kunnande som härrör ur flickiga erfarenheter tystas ner eller glöms bort. I antologin centreras sådana flickiga epistemologier på ett kreativt och inkännande sätt, och görs till verktyg i den kritiska undersökningen av akademiska och sceniska rum. Exempelvis infiltreras det akademiska konferensrummet med skarp flickblick: vad skulle hända om den som presenterade forskning istället för att stå och föreläsa med stram hållning viskade fram det hen ville förmedla till publiken, som om det vore en hemlighet? Eller gav sin keynote sittande under bordet, som i en koja? Exemplen, som är hämtade från en experimentell workshop där skådespelarna i projektet givit regi åt forskarna, belyser hur kunskaper och metoder från scenkonstvärlden kan öppna upp för utmaningar av akademiska normer. De synliggör också vad sammanhang som förknippas med stringens och seriositet kan vinna på att på allvar låta sig utmanas och påverkas av lek. Det kan handla om att destabilisera makt- och statusskillnader mellan föreläsare och publik, eller om att synliggöra kroppens och känslornas betydelse i en kontext där dessa vanligtvis inte får ta plats.

I texten "Ska vi leka?" beskriver scenkonstnären Maria Grudemo el Hayek Girling together-projektet som "en grupp flickor som arbetat tillsammans" i syfte att möjliggöra ett möte mellan "vuxenvärlden och barnvärlden" (20I9, 93) likaväl som mellan de två skilda yrkessfärerna. Detta angreppssätt, som beskrivs mer ingående i kapitlet "Leka metod", uttrycker en vägran att ställa det flickiga i motsats till meningsfullhet 
och kunskapsproduktion - liksom att framställa det som reserverat för människor i en viss ålder. I antologin är flickan en tankefigur, en position som inte nödvändigtvis motsvaras av en viss typ av kropp eller kronologisk ålder. Att inta denna position öppnar upp för sätt att tänka bortom de vuxna, maskulina ideal som tas för givna och därtill uppfattas som neutrala.

Detta positionstagande innebär emellertid att utsätta sig för risken att framstå som kulturellt obegriplig. I texten ”Tänk om tjejvärldar är de bästa av världar?” skildrar Forsell publikreaktionerna på PotatoPotatos föreställning Radikal vänskap. Hon återger hur en åskådare uttryckt att skådespelarna borde ha förvarnat om att ingenting skulle hända $\mathrm{i}$ pjäsen, så att publiken inte hade behövt sitta där och vänta på att något skulle hända. Att engagera sig i flickiga lekar och praktiker innebär således inte bara att ta sig an något nedvärderat, utan även att riskera att det man gör inte uppfattas som att göra någonting över huvud taget. Men som antologin förtjänstfullt synliggör, är detta också en del av den kreativa och subversiva potentialen. En röd tråd som binder texterna samman är betydelsen av kollektivitet. I performancekonstnären Lena Bondesons text länkas flickighet samman med att ingå i kollektiva gemenskaper som förlöjligas av utomstående, men som samtidigt kan ligga till grund för nya former av meningsskapande och motstånd. Betoningen av kollektivitet i antologin ruskar om de förhärskande kulturella föreställningar som uttrycker att flickor konkurrerar med varandra och inte kan vara tillsammans i grupp. Det är gemensamma praktiker som står i centrum, just som titeln uttrycker: girling together.

Utgångspunkten i olika fält reflekteras inte enbart innehållsmässigt utan även form- och stilmässigt; antologin utgörs av feministiska analyser, metoddiskussioner, reflektioner med utgångspunkt i personliga erfarenheter, poetiska texter och bildmaterial. På så vis formas ett rikt kollage som erbjuder snabba inblickar i olika flickrum och flickerfarenheter. På grund av formatet - de flesta av texterna upptar endast ett par sidor - lämnas dock inte mycket utrymme för fördjupning. Flera bidrag pekar mot intressanta problemkomplex som antologin hade vunnit på att dröja kvar i. I inledningen finns exempelvis en passage där använd- 
ningen av fickan i singular problematiseras, men antologin innehåller få vidare reflektioner kring hur det flickigas innebörder och möjligheter, liksom tillgången till flickiga gemenskaper, villkoras av exempelvis klass, rasifiering, sexualitet och funktionalitet.

Ännu en möjlighet till komplicering och nyansering ser jag i hur löftena i samverkan mellan konstnärliga och akademiska fält framställs. I antologin finns en tendens till att gestalta scenkonsten som det radikala och nytänkande, som i mötet med en stelbent akademi kan inspirera och förändra den senare. Men feministiska akademiska kontexter och uttryck är, i likhet med konstnärliga, inte enhetliga. Genom att exempelvis diskutera kreativa skrivformer inom svensk flickforskning och femme-ininitetsteori, hade antologin kunnat tydliggöra hur konstnärliga praktiker också redan är en del av ett teoretiskt utforskande av flickskap, på liknande vis som feministisk teori redan formar scenkonsten.

Sammanfattningsvis är Girling together: A dialogue ett viktigt bidrag till de kritiska och kreativa samtal om ung femininitet, lek, motstånd och fluktuerande ålderspositioner bortom linjära kronologier som pågår såväl inom som utanför akademin. Bokens främsta styrka är hur den, genom att komplicera dikotomiseringen mellan flickiga praktiker och kunskapsproduktion, övertygande visar att det flickiga inte bara utgör ett viktigt ämne att forska eller göra scenkonst om. Lika mycket är det att förstå som en uppsättning kunskaper och förhållningssätt som kan bidra till metodutveckling inom vetenskapligt och konstnärligt arbete. 